\title{
STUDI MUTU KAYU JATI DI HUTAN RAKYAT GUNUNGKIDUL IV. SIFAT MEKANIKA KAYU
}

\section{SRI NUGROHO MARSOEM*, VENDY EKO PRASETYO, JOKO SULISTYO, SUDARYONO, \& GANIS LUKMANDARU}

\author{
Bagian Teknologi Hasil Hutan, Fakultas Kehutanan, Universitas Gadjah Mada \\ J1. Agro No 1, Bulaksumur, Sleman 55281 \\ *Email:snmarsoem@ugm.ac.id
}

\begin{abstract}
Mechanical properties of sawn timber are the most important characteristics in many applications, particularly for structural timber. The previous paper in this series reported on the physical properties of teak trees at different sites (Panggang, Playen, Nglipar) from community forests in Gunungkidul regency. In this study, the mechanical properties were evaluated according to British Standards 373:57. The results showed that the timber were classified in the II-III of strength class. By analysis of variance, site factor affected the values of modulus of rupture (MoR) in statical bending strength, maximum compression perpendicular to grain strength, shear strength and hardness. In general, except for MoR, the wood samples from Nglipar gave higher strength levels. Except for cleavage strength, the effects of the axial and radial position of the tree on mechanical properties were mostly negligible. Although linearly related, only modest correlations were observed between the mechanical parameters (MoR/shear strength) and basic density. No significant correlation was found between the values of basic density and modulus of elasticity of static bending strength as well as between basic density and the strength of maximum compression parallel to grain.
\end{abstract}

Keywords: Tectona grandis, mechanical properties, basic density, community forest, Gunungkidul.

\section{INTISARI}

Sifat mekanika dari kayu gergajian adalah persyaratan terpenting dalam banyak penerapan khususnya untuk keperluan konstruksi. Paper ini merupakan lanjutan dari penelitian sifat fisika kayu di tiga tempat tumbuh (Panggang, Playen, Nglipar) hutan rakyat Kabupaten Gunungkidul. Pengujian sifat mekanika dilakukan mengacu pada British Standards 373:57. Hasil penelitian menunjukkan bahwa kayu yang diteliti termasuk dalam kelas kuat II-III. Dari perhitungan analisis varian, tempat tumbuh berpengaruh nyata pada modulus patah (MoR) keteguhan lengkung statik, keteguhan tekan tegak lurus serat maksimum, keteguhan geser, dan kekerasan. Secara keseluruhan, kecuali untuk nilai MoR, sampel kayu dari Nglipar memberikan nilai kekuatan yang lebih tinggi. Pengaruh arah aksial dan radial pohon secara umum tidak begitu terlihat pada semua parameter kekuatan kecuali di keteguhan belah. Meskipun berkorelasi secara linier, hanya korelasi moderat yang diamati dari hubungan sifat mekanika (MoR/keteguhan geser) dan kerapatan dasar. Tidak ada korelasi nyata antara kerapatan dasar dan modulus elastisitas keteguhan lengkung statik serta antara kerapatan dasar dan keteguhan tekan sejajar serat maksimum.

Kata kunci: Tectona grandis, sifat mekanika, kerapatan dasar, hutan rakyat, Gunungkidul. 


\section{PENDAHULUAN}

Kebijakan dalam pengembangan industri kehutanan selalu berpengaruh besar terhadap ketersediaan kayu untuk berbagai penggunaan. Kesenjangan antara persediaan dan permintaan menyebabkan intensitas penggunaan kayu dari hutan rakyat selalu meningkat. Sebagai gambaran, produksi kayu bulat secara nasional di tahun 2011 dari hutan rakyat dan perkebunan mencapai 2.828 .037 dan $428.240 \mathrm{~m}^{3}$, secara berturutan, sedangkan dari hutan tanaman Perhutani sebesar $112.858 \mathrm{~m}^{3}$ (Kementerian Kehutanan, 2012). Oleh karena itu, penanaman pohon jati secara masif di hutan rakyat banyak dilakukan karena kayunya yang secara tradisional dapat digunakan di berbagai produk akhir dan harga relatif tinggi, khususnya di Jawa.

Sifat dasar kayu menjadi penting untuk diketahui untuk kesesuaiannya dalam berbagai pemanfaatan. Sebagai bahan baku alami, sifat kayu sangat bervariasi karena dipengaruhi faktor luar. Hutan rakyat dalam prakteknya juga bervariasi dalam perlakuan silvikulturnya maupun kondisi lingkungannya. Dalam industri perkayuan, sifat kayu yang lebih seragam akan memudahkan dalam pengolahannya. Hal ini mengharuskan untuk memahami pola variasi dalam sifat kayu (variasi dalam ketinggian pohon dan dalam hati menuju kulit) serta pengaruh beda umur, beda tempat tumbuh, dan kondisi lingkungan. Tantangan yang dihadapi adalah masih terbatasnya informasi sifat kayu jati yang berasal dari hutan rakyat.

Kayu jati dengan berbagai keunggulan sifatnya merupakan pilihan utama untuk tujuan konstruksi dimana sifat kekuatan atau mekanika kayu menjadi pembatas. Praktek selama ini di hutan rakyat adalah dengan memanen karena kebutuhan (tebang butuh) yang umumnya dilakukan pada usia muda bila dibandingkan jati konvensional. Penelitian sifat kekuatan jati dari pohon usia muda dan hasil pemuliaan di Indonesia telah dilakukan (Wahyudi dan Arifien, 2005; Hadjib et al., 2006; Yunianti et al., 2011, Hidayati et al., 2014) untuk mendapatkan bahan baku alternatif dari kayu yang tumbuh secara konvensional di hutan tanaman Perhutani. Penelitian ini merupakan lanjutan dari eksplorasi sifat fisik kayu jati di tiga tempat tumbuh hutan rakyat Kabupaten Gunungkidul (Marsoem et al., 2014). Sifat mekanika dipengaruhi oleh banyak faktor yang salah satunya adalah kerapatan kayunya (Shmulsky dan Jones, 2011; Dresch dan Dinwoodie, 1996). Oleh karena itu, selain mengetahui variasi karena tempat tumbuh dan di dalam pohon, penelitian ini juga bertujuan menghubungkan kerapatan dasar dengan sifat kekuatan kayunya.

\section{BAHAN DAN METODE}

\section{Penyiapan Sampel}

Deskripsi mengenai tegakan, faktor klimatis, dan tempat tumbuh telah dijabarkan di penelitian sebelumnya (Marsoem et al., 2014). Sebanyak tiga pohon yang relatif bebas cacat dan lurus ditebang (diameter 28-37 cm) di setiap tempat di hutan rakyat Gunungkidul yaitu di Desa Girisekar (Panggang), Desa Dengok (Playen), dan Desa Kedungkeris (Nglipar). Bagian batang yang diperoleh dibagi menjadi 3 berdasarkan ketinggiannya dari bebas cabangnya yaitu pangkal, tengah, dan ujung. Di setiap bagian aksial tersebut, dipotong $40 \mathrm{~cm}$ dari bagian bawah dan digergaji papan secara sejajar (flat-sawn). Dari papan tersebut kemudian dipotong sampel dalam satu arah jari-jari yang dipilih yaitu dalam arah barat pohon (90 derajat). Selanjutnya, untuk pengujian sifat mekanika kayu di arah radial yaitu dekat hati/empulur $( \pm 1 \mathrm{~cm}$ dari hati), tengah, dan dekat kulit $( \pm 0,5 \mathrm{~cm}$ dari kulit) sehingga 
diperoleh total 81 spesimen. Skema pengambilan sampel disajikan pada Gambar 1.

\section{Pengujian Sifat Mekanika}

Parameter kekuatan meliputi keteguhan lengkung statik (KLS) untuk mendapatkan nilai batas proporsi, modulus elastisitas (MoE) dan modulus patah/rupture (MoR). Parameter lainnya meliputi keteguhan tekan pada arah sejajar serat maksimum (KTSS) dan tegak lurus serat maksimum (KTTLS), kekerasan, keteguhan geser, dan keteguhan belah. Pengujian dilakukan mengacu pada standar British 373:57 untuk spesimen kecil bebas cacat. Spesimen diuji dalam kondisi kering udara. Alat yang digunakan adalah Universal Testing Machine (UTM) model Instron.

\section{Penentuan Kerapatan Dasar}

Data dari kerapatan dasar (KD) diperoleh dari laporan sebelumnya (Marsoem et al., 2014) untuk posisi yang bersesuaian dengan sampel mekanika. Sampel berukuran 2 × 2 × $2 \mathrm{~cm}$ diukur berat kering tanur $\left(103 \pm 2^{\circ} \mathrm{C}\right)$ dan volume basahnya. KD dihitung dari pembagian berat kering tanur kayu dibagi volume basah kayu.

\section{Analisis Data}

Analisis variansi (ANOVA) dipakai untuk menguji hipotesa nol jika rerata kelompok dari tempat tumbuh, arah aksial, dan arah radial adalah sama dalam populasi melalui perbandingan antar variansi sampel. Pengaruh dinyatakan nyata dalam taraf uji 5\% melalui penjumlahan kuadrat Tipe III. Uji pembanding berganda Duncan dihitung untuk mengetahui kelompok mana yang berbeda nyata. Korelasi Pearson digunakan untuk mengetahui keeratan hubungan yang ditandakan oleh koefisien korelasi (r) antara KD yang diperoleh dari penelitian sebelumnya dengan parameter-parameter mekanika kayu serta antar parameter mekanika kayu itu sendiri. Perhitungan statistik memakai software SPSS 16.0 (Windows).

\section{HASIL DAN PEMBAHASAN}

\section{Sifat Mekanika Kayu}

MoE/MoR dan KTSS merupakan sifat-sifat yang paling dipertimbangkan dalam penggunaan kayu pejal dan paling mendapat banyak perhatian sehubungan dengan adanya kayu jati yang cepat tumbuh (Thulasidas dan Bhat, 2012). Dalam eksperimen ini, beberapa parameter mekanika lainnya ditambahkan sehingga mendapatkan gambaran sifat

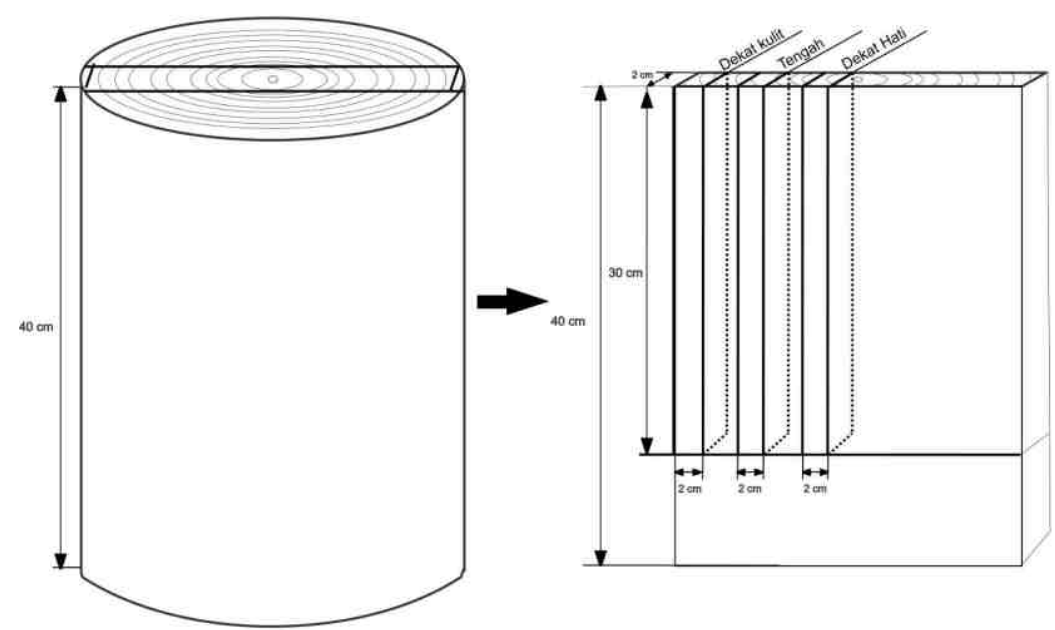

Gambar 1. Skema pengambilan spesimen uji sifat mekanika kayu jati dalam arah radial. 
mekanik yang lebih menyeluruh. Hasil pengujian beberapa parameter kekuatan kayu dari 3 tempat tumbuh dirangkum dalam Tabel 1. Beberapa parameter menunjukkan kisaran yang lebar dimana apabila dihitung nilai koefisien variasinya nilainya di atas $20 \%$ di dalam satu lokasi seperti pada parameter keteguhan geser, belah, dan kekerasan. Untuk itu, pengambilan jumlah individu pohon perlu diperbesar untuk mengurangi kisaran yang lebar tersebut untuk penelitian ke depannya.

Sebagai pembanding dari Martawijaya et al. (2005) yaitu nilai KLS (batas proporsi $718 \mathrm{~kg} / \mathrm{cm}^{2}$; MoE 127,7 x 10 $10^{3} \mathrm{~kg} / \mathrm{cm}^{2}$, MoR $1031 \mathrm{~kg} / \mathrm{cm}^{2}$ ), kekerasan (414 dan $\left.418 \mathrm{~kg} / \mathrm{cm}^{2}\right)$, KTSS (550 $\left.\mathrm{kg} / \mathrm{cm}^{2}\right)$, dan geser $\left(80\right.$ dan $\left.89 \mathrm{~kg} / \mathrm{cm}^{2}\right)$ menunjukkan nilai jati Gunungkidul ini untuk KLS, kekerasan, dan KTSS masih di bawah sedangkan tegangan gesernya lebih tinggi. Nilai MoE, MoR, dan kekerasan dalam penelitian ini lebih tinggi dari yang dipublikasikan Hadjib et al. (2006) untuk beberapa jati super dan lokal yang berumur muda (4-7 tahun), yaitu nilai MoE 20-54 x 10 3 kg/ $\mathrm{cm}^{2}$, MoR 243-529 kg/ $\mathrm{cm}^{2}$, dan kekerasan $199-327 \mathrm{~kg} / \mathrm{cm}^{2}$. Nilai penelitian ini masih dalam kisaran jati konvensional 8 tahun (Wahyudi dan Arifien, 2005) yaitu nilai MoE sekitar 42-86 x $10^{3} \mathrm{~kg} / \mathrm{cm}^{2}$ dan MoR $640-960 \mathrm{~kg} / \mathrm{cm}^{2}$ maupun jati klon (7 tahun) dengan nilai MoE 78-86 x 10 3 kg/ $\mathrm{cm}^{2}$ (Yunianti et al., 2011). Nilai KTSS lebih rendah dari jati klon Perhutani (12 tahun) (Hidayati et al., 2014) yaitu setara 386 dan $398 \mathrm{~kg} / \mathrm{cm}^{2}$. Apabila dibandingkan dengan data jati dari Perhutani di KU IV, VI, dan VIII (Sulistyo dan Marsoem, 2000) yaitu KLS $113-144 \times 10^{3} \mathrm{~kg} / \mathrm{cm}^{2}$ (MoE) dan $983-1.108 \mathrm{~kg} / \mathrm{cm}^{2}$ (MoR) serta KTTLSS $162-233 \mathrm{~kg} / \mathrm{cm}^{2}$, maka nilai KLS jati di Gunungkidul ini lebih rendah sedangkan nilai parameter KTTLSS masih dalam kisarannya. Dari analisa lingkaran tahunnya, sampel jati yang digunakan di penelitian ini dalam kisaran umur 10-21 tahun yang diasumsikan masih dalam fase juvenil,

Tabel 1. Kerapatan dasar dan sifat mekanika kayu jati dari hutan rakyat Kabupaten Gunungkidul.

\begin{tabular}{|c|c|c|c|c|c|c|c|c|c|}
\hline \multirow{2}{*}{$\begin{array}{c}\text { Parameter } \\
\text { fisik/keteguhan }\end{array}$} & \multicolumn{3}{|c|}{ Panggang } & \multicolumn{3}{|c|}{ Playen } & \multicolumn{3}{|c|}{ Nglipar } \\
\hline & Min. & Maks. & $\begin{array}{l}\text { Rerata } \\
\text { (sd) }\end{array}$ & Min. & Maks. & $\begin{array}{l}\text { Rerata } \\
\text { (sd) }\end{array}$ & Min. & Maks. & $\begin{array}{c}\text { Rerata } \\
\text { (sd) }\end{array}$ \\
\hline Kerapatan dasar & 525 & 619 & $\begin{array}{l}566,33 \\
(29,71)\end{array}$ & 555 & 672 & $\begin{array}{l}596,22 \\
(38,64)\end{array}$ & 504 & 628 & $\begin{array}{l}564,44 \\
(38,88)\end{array}$ \\
\hline $\begin{array}{l}\text { LS } \quad-\quad \text { Batas } \\
\text { proporsi }\left(\mathrm{kg} / \mathrm{cm}^{2}\right)\end{array}$ & 366,81 & 666,01 & $\begin{array}{c}512,32 \\
(110,72)\end{array}$ & 434,68 & 680,52 & $\begin{array}{c}580,95 \\
(110,04)\end{array}$ & 399,54 & 784,38 & $\begin{array}{c}563,17 \\
(175,49)\end{array}$ \\
\hline $\begin{array}{ll}\mathrm{LS} & - \\
\left(\mathrm{kg} / \mathrm{cm}^{2}\right)^{-} & \text {MoR }\end{array}$ & 651,57 & 920,02 & $\begin{array}{c}794,43 \\
(111,21)\end{array}$ & 845,36 & 1001,94 & $\begin{array}{c}887,88 \\
(121,02)\end{array}$ & 749,24 & 977,65 & $\begin{array}{c}835,25 \\
(144,78)\end{array}$ \\
\hline $\begin{array}{l}\mathrm{LS}-\mathrm{MoE}(\mathrm{x} 1000 \\
\left.\mathrm{kg} / \mathrm{cm}^{2}\right)\end{array}$ & 57,01 & 95,59 & $\begin{array}{c}81,60 \\
(15,38)\end{array}$ & 82,10 & 93,25 & $\begin{array}{c}87,46 \\
(10,46)\end{array}$ & 69,83 & 94,39 & $\begin{array}{c}88,65 \\
(16,71)\end{array}$ \\
\hline TTLS $\left(\mathrm{kg} / \mathrm{cm}^{2}\right)$ & 122,89 & 210,81 & $\begin{array}{l}155,78 \\
(42,16)\end{array}$ & 168,66 & 250,03 & $\begin{array}{l}202,31 \\
(39,25)\end{array}$ & 192,09 & 251,66 & $\begin{array}{l}222,56 \\
(40,28)\end{array}$ \\
\hline $\operatorname{TSS}\left(\mathrm{kg} / \mathrm{cm}^{2}\right)$ & 246,79 & 388,44 & $\begin{array}{l}328,91 \\
(59,57)\end{array}$ & 312,94 & 387,04 & $\begin{array}{l}348,63 \\
(42,89)\end{array}$ & 311,13 & 390,78 & $\begin{array}{l}350,85 \\
(61,49)\end{array}$ \\
\hline $\begin{array}{l}\text { Kekerasan } \\
\left(\mathrm{kg} / \mathrm{cm}^{2}\right)\end{array}$ & 278,66 & 504,24 & $\begin{array}{c}382,77 \\
(132,19)\end{array}$ & 331,74 & 597,13 & $\begin{array}{c}452,64 \\
(159,68)\end{array}$ & 305,20 & 690,02 & $\begin{array}{c}511,61 \\
(181,32)\end{array}$ \\
\hline $\operatorname{Geser}\left(\mathrm{kg} / \mathrm{cm}^{2}\right)$ & 59,05 & 135,03 & $\begin{array}{c}97,27 \\
(27,88)\end{array}$ & 94,86 & 163,08 & $\begin{array}{l}119,58 \\
(32,36)\end{array}$ & 91,98 & 144,65 & $\begin{array}{l}120,96 \\
(24,27)\end{array}$ \\
\hline Belah $(\mathrm{kg} / \mathrm{cm})$ & 13,50 & 19,65 & $\begin{array}{l}17,57 \\
(1,56)\end{array}$ & 13,37 & 17,97 & $\begin{array}{l}16,55 \\
(1,99)\end{array}$ & 14,07 & 22,47 & $\begin{array}{l}18,65 \\
(1,75)\end{array}$ \\
\hline
\end{tabular}

Keterangan $:$ min. $=$ minimum; maks. = maksimum; $\mathrm{sd}=$ standar deviasi; $\mathrm{LS}=$ lengkung statik; MoR = batas patah; $\mathrm{MoE}=$ modulus elastisitas; TTLS = tekan tegak lurus serat; TSS = tekan sejajar serat 
sehingga masih dimungkinkan terjadi peningkatan kekuatan seiring umur (Bhat et al., 2001).

Berdasarkan kisaran nilai MoR dan KTSS, maka jati Gunungkidul ini termasuk dalam kelas kuat II-III (Martawijaya et al., 2005). Jati superior diharapkan memenuhi persyaratan penggunaan akhir seperti nilai MoR > $135 \mathrm{~N} / \mathrm{mm}^{2}$ atau setara $1.376 \mathrm{~kg} / \mathrm{cm}^{2}$ (Miranda et al., 2011). Nilai tersebut tidak dicapai di penelitian ini dan masuk di persyaratan kelas kuat I $\left(\mathrm{MoR}>1.100 \mathrm{~kg} / \mathrm{cm}^{2}\right)$. Nilai tertinggi didapatkan pada sampel Nglipar dengan nilai MoR 95,9 N/mm² (kelas kuat II). Untuk itu, apabila sifat mekanika bisa diwariskan, tentunya bibit unggul yang tersebar di Gunungkidul ke depannya diharapkan menghasilkan kayu yang tergolong kelas kuat II untuk keperluan kayu bangunan atau konstruksi berat.

Nilai MoE yang tinggi menunjukkan kekakuan kayu yang tinggi yaitu kemampuan menahan lengkung yang tinggi, sedangkan MoE yang rendah menunjukkan kayu yang kurang kaku atau mudah dilengkungkan. MoR menunjukkan batas kekuatan maksimum kayu tersebut sampai rusak. Hasil ANOVA menunjukkan bahwa tidak ada interaksi nyata pada ketiga faktor pada parameter KLS,

'Iabel 2. Analısıs varıan darı keteguhan lengkung statık kayu jatı darı hutan rakyat Kabupaten Gunungkidul.

\begin{tabular}{|c|c|c|c|c|c|c|c|}
\hline \multirow{3}{*}{$\begin{array}{l}\text { Sumber } \\
\text { variasi }\end{array}$} & \multirow{3}{*}{$\mathrm{db}$} & \multicolumn{6}{|c|}{ Keteguhan Lengkung Statik } \\
\hline & & \multicolumn{2}{|c|}{ Batas proporsi } & \multicolumn{2}{|c|}{ MoR } & \multicolumn{2}{|c|}{$\mathrm{MoE}$} \\
\hline & & KT & $\mathrm{F}$ & KT & $\mathrm{F}$ & KT & $\mathrm{F}$ \\
\hline $\mathrm{T}$ & 2 & 32950,68 & 2,35 & 59485,40 & $3,50^{*}$ & 310,22 & 1,77 \\
\hline A & 2 & 205614,44 & 1,09 & 11287,70 & 0,66 & 333,19 & 1,90 \\
\hline $\mathrm{R}$ & 2 & 101496,63 & $4,80^{*}$ & 27125,73 & 1,59 & 411,25 & 2,34 \\
\hline TxA & 4 & 37546,63 & 1,63 & 32181,09 & 1,89 & 441,23 & 2,51 \\
\hline TxR & 4 & 9165,12 & 0,33 & 4126,98 & 0,24 & 135,01 & 0,77 \\
\hline AxR & 4 & 2825,72 & 0,20 & 1863,81 & 0,11 & 304,16 & 1,73 \\
\hline TxAxR & 8 & 5858,00 & 0,30 & 11929,33 & 0,70 & 298,90 & 1,70 \\
\hline Galat & 54 & 10497,85 & & 16976,60 & & 175,15 & \\
\hline
\end{tabular}

Keterangan : T : tempat tumbuh; A : arah aksial; $\mathrm{R}$ : arah radial; db : derajat bebas; MoE : modulus elastisitas; MoR : batas patah; KT : rerata kuadrat tengah

$* *$ = beda sangat nyata pada taraf uji $1 \% \quad *=$ beda nyata pada taraf uji $5 \%$
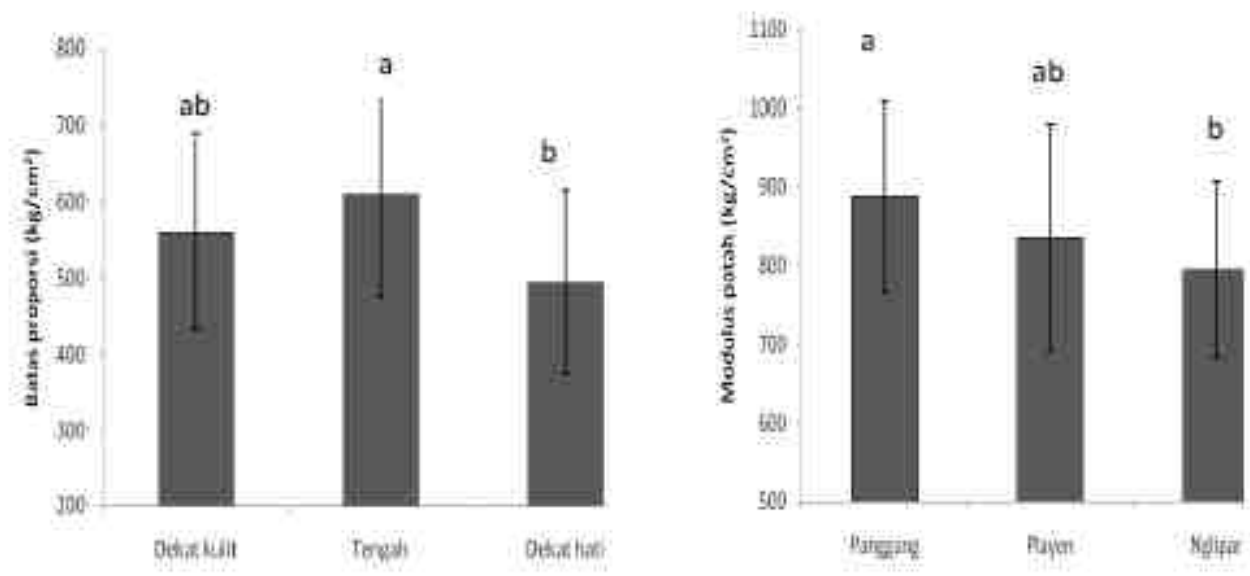

Gambar 2. Keteguhan lengkung statik kayu jati dari hutan rakyat Kabupaten Gunungkidul. Huruf yang sama menunjukkan tidak beda nyata pada taraf uji $5 \%$ dalam uji Duncan. 
Tabel 3. Analisis varian dari keteguhan tekan, geser, belah, dan kekerasan kayu jati dari hutan rakyat Kabupaten Gunung Kidul.

\begin{tabular}{|c|c|c|c|c|c|c|c|c|c|c|c|}
\hline \multirow{3}{*}{$\begin{array}{l}\text { Sumber } \\
\text { variasi }\end{array}$} & \multirow{3}{*}{$\mathrm{db}$} & \multicolumn{10}{|c|}{ Keteguhan } \\
\hline & & \multicolumn{2}{|c|}{$\begin{array}{c}\text { Tekan sejajar } \\
\text { serat maksimum }\end{array}$} & \multicolumn{2}{|c|}{$\begin{array}{l}\text { Tekan tegak lurus } \\
\text { serat maksimum }\end{array}$} & \multicolumn{2}{|c|}{ Geser } & \multicolumn{2}{|c|}{ Kekerasan } & \multicolumn{2}{|c|}{ Belah } \\
\hline & & KT & $\mathrm{F}$ & KT & $\mathrm{F}$ & KT & $\mathrm{F}$ & KT & $\mathrm{F}$ & KT & $\mathrm{F}$ \\
\hline $\mathrm{T}$ & 2 & 3939,11 & 1,42 & $31655,91 * *$ & 18,41 & $4748,75^{* *}$ & 5,49 & $129655,34^{*}$ & 4,88 & 0,44 & 0,17 \\
\hline A & 2 & 1878,28 & 0,67 & 551,43 & 0,32 & 619,76 & 0,71 & 26414,95 & 0,99 & 9,84 & $3,94 *$ \\
\hline $\mathrm{R}$ & 2 & 3486,75 & 1,25 & 4317,86 & 2,51 & 2022,44 & 2,33 & 4636,09 & 0,17 & 0,40 & 0,16 \\
\hline TxA & 4 & 6904,15 & 2,48 & 1597,67 & 0,92 & 562,64 & $0, .65$ & 6356,19 & 0,24 & 1,29 & 0,52 \\
\hline TxR & 4 & 2704,01 & 0,97 & 1507,62 & 0,87 & 779,90 & 0,90 & 6018,69 & 0,22 & 9,91 & $3,97^{* *}$ \\
\hline AxR & 4 & 2366,80 & 0,85 & 1336,84 & 0,77 & 178,32 & 0,20 & 20634,78 & 0,77 & 7,11 & $2,85^{*}$ \\
\hline TxAxR & 8 & 3744,12 & 1,35 & 1003,09 & 0,58 & 587,17 & 0,67 & 25880,66 & 0,97 & 2,15 & 0,86 \\
\hline Galat & 54 & 2774,07 & & 1719,17 & & 864,721 & & 26529,33 & & 2,49 & \\
\hline
\end{tabular}

Keterangan : lihat Tabel 2

pengaruh nyata diamati pada faktor tunggal arah radial di batas proporsi dan tempat tumbuh di modulus patah (Tabel 2). Analisis lebih lanjut (Gambar 2) menunjukkan bahwa dalam arah radial bagian dekat hati mempunyai nilai rerata batas proporsi terendah $\left(494,34 \mathrm{~kg} / \mathrm{cm}^{2}\right)$, sedangkan rerata modulus patah tertinggi diamati di sampel dari Panggang $\left(887,88 \mathrm{~kg} / \mathrm{cm}^{2}\right)$.

Hasil ANOVA (Tabel 3) pada parameter selain KLS menunjukkan adanya interaksi nyata di 2 faktor seperti pada keteguhan belah (tempat tumbuh $\mathrm{x}$ arah radial dan arah radial $\mathrm{x}$ arah aksial). Pengaruh faktor tempat tumbuh diamati pada keteguhan tekan tegak lurus serat, kekerasan, dan geser sedangkan tidak ada faktor yang berpengaruh nyata pada keteguhan tekan sejajar serat. Berdasarkan tempat tumbuhnya, sampel dari Playen cenderung memberikan nilai rerata terendah pada keteguhan tekan tegak lurus serat $\left(155,78 \mathrm{~kg} / \mathrm{cm}^{2}\right)$, geser $\left(97,26 \mathrm{~kg} / \mathrm{cm}^{2}\right)$, dan kekerasan $\left(382,77 \mathrm{~kg} / \mathrm{cm}^{2}\right)$, sedangkan nilai tertinggi diamati pada sampel Nglipar (Gambar 3). Pengamatan lebih detail melalui uji Duncan di keteguhan belah disajikan pada Gambar 4. Terlihat bahwa kecenderungan pada arah radial bervariasi menurut tempat tumbuhnya, terjadi penurunan nilai dari dekat kulit ke dekat hati/empulur di sampel Panggang dan kenaikan pada sampel Nglipar. Nilai rerata tertinggi diukur di sampel Panggang dekat kulit $(21,05 \mathrm{~kg} / \mathrm{cm})$ dan Nglipar dekat hati $(21,00 \mathrm{~kg} / \mathrm{cm})$. Dalam interaksi tempat tumbuh dan arah aksial batang dapat dilihat kenaikan dari dekat kulit ke dekat hati di bagian pangkal serta pola berlawanan di bagian tengah dan ujung dengan nilai tertinggi diamati pada bagian ujung batang di dekat kulit $(21,17 \mathrm{~kg} / \mathrm{cm})$.

\section{Pengaruh Faktor Internal dan Tempat Tumbuh}

Faktor tempat tumbuh secara tunggal maupun interaksi dengan faktor internal berpengaruh nyata terhadap beberapa parameter mekanika kayu. Hadjib et al. (2006) mendapatkan pengaruh tempat tumbuh yang nyata pada sifat kekakuan dan MoR dari jati super dan lokal di umur muda. Penelitian sebelumnya di jati India berdasarkan perbedaan tempat tumbuh menunjukkan nilai $\mathrm{MoE}$ dan MoR lebih rendah karena lebih banyaknya sel parenkim dan rendahnya persen serat dalam lingkaran tahun yang lebih sempit yang diduga karena adaptasi kondisi 


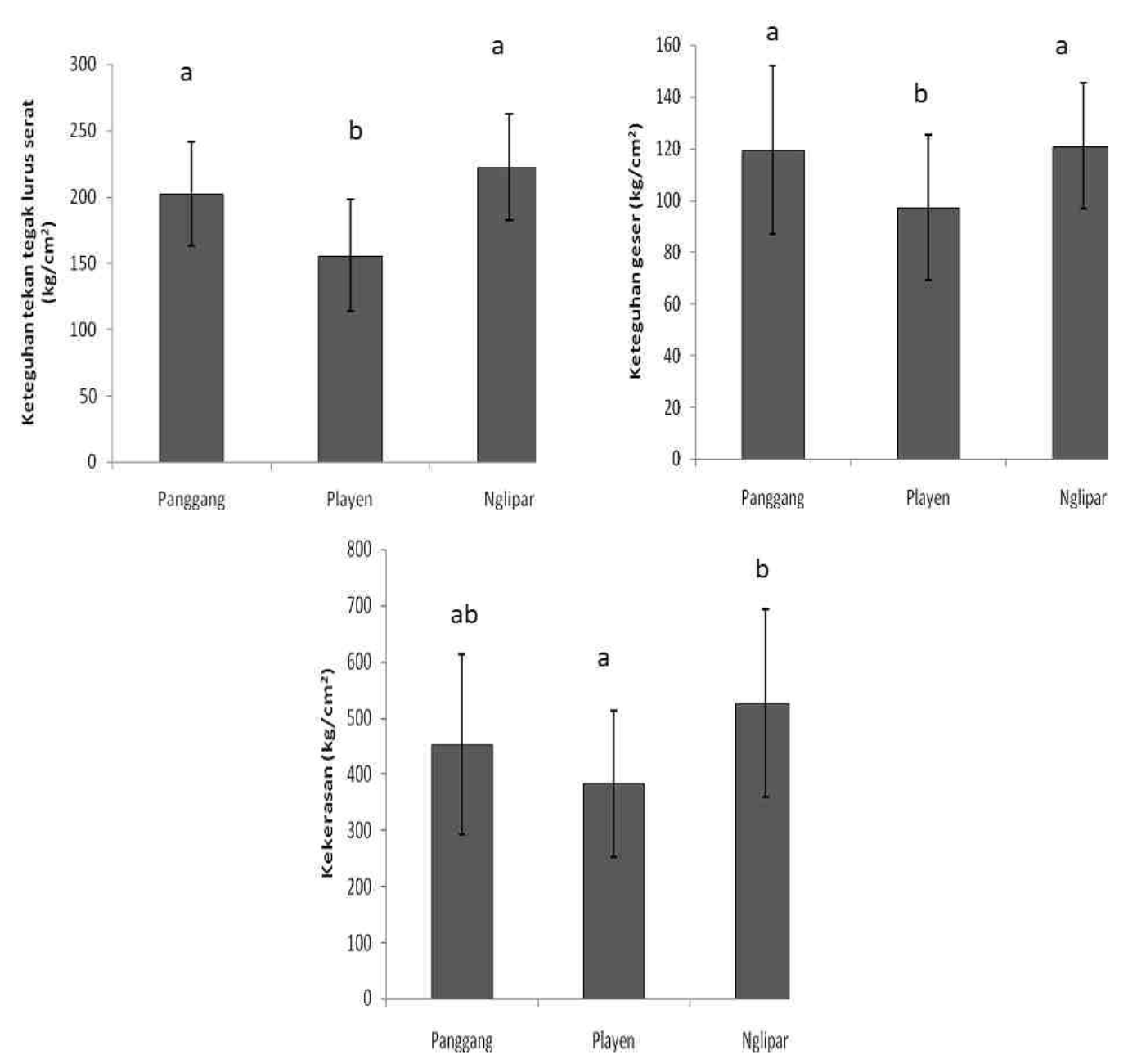

Gambar 3. Keteguhan tekan tegak lurus serat maksimum, geser, dan kekerasan kayu jati dari hutan rakyat Kabupaten Gunungkidul. Huruf yang sama menunjukkan tidak beda nyata pada taraf uji 5\% dalam uji Duncan di parameter yang sama.
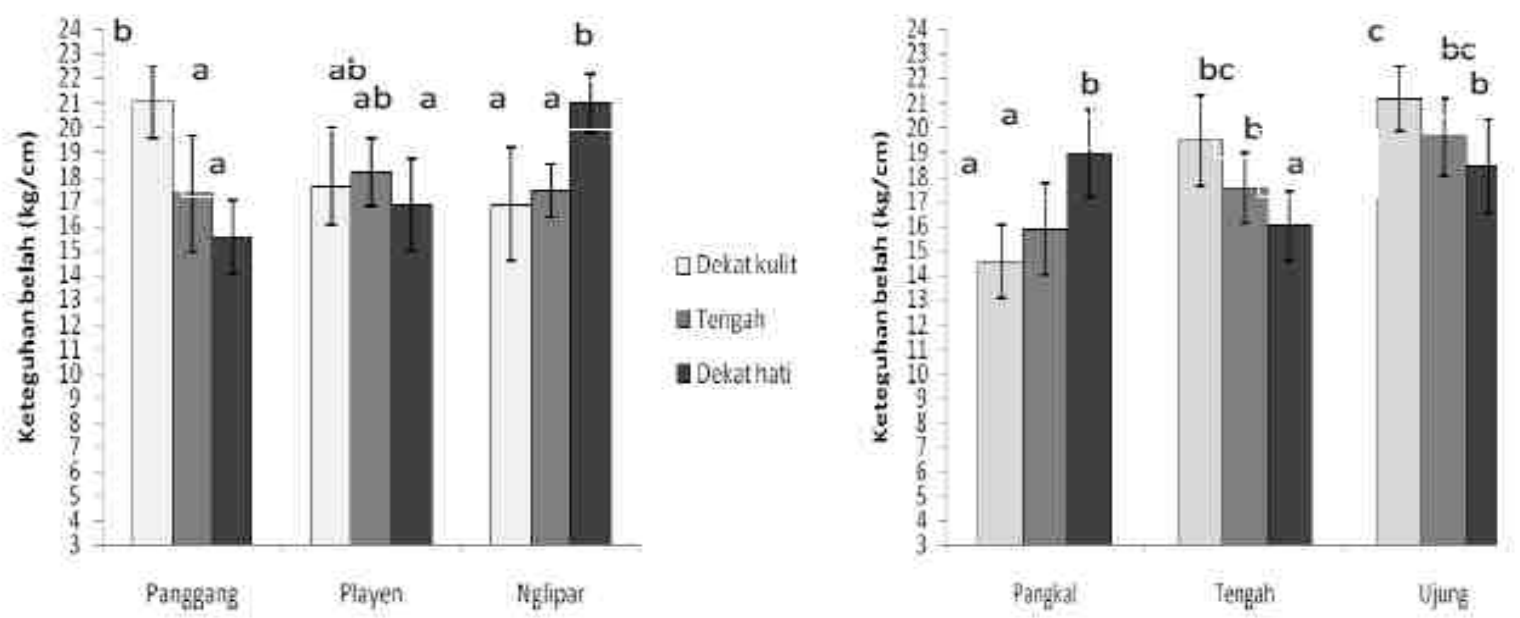

Gambar 4. Keteguhan belah kayu jati dari hutan rakyat Kabupaten Gunungkidul. Huruf yang sama menunjukkan tidak beda nyata pada taraf uji 5\% dalam uji Duncan.

tanah yang lebih subur (Bhat dan Priya, 2004). Masih di India, kayu jati umur 35 tahun dari kebun tumbuh di daerah kering mempunyai nilai KTSS yang lebih tinggi dibandingkan di daerah basah tetapi tidak 
berpengaruh nyata pada MoE dan MoR (Thulasidas dan Bhat, 2012). Curah hujan dalam tahun 20092012 menunjukkan daerah Panggang yang tertinggi (Marsoem, 2013). Meski demikian, belum diketahui secara pasti sampai seberapa besar pengaruh faktor hujan ini pada variasi kekuatan antar tempat tumbuh di atas. Kondisi tanah di daerah Panggang diasumsikan yang paling tidak subur karena top soil yang tipis dan berbatu dibandingkan kedua tempat tumbuh lainnya. Dalam penelitian ini, rerata MoR di daerah Panggang menunjukkan nilai tertinggi (Gambar 2). Untuk itu, analisa tanah dan sifat anatomi kayu diperlukan untuk menjawab fenomena tersebut termasuk rendahnya nilai rerata KTTLS, geser, dan kekerasan di Playen.

Pengaruh nyata arah aksial terlihat hanya di keteguhan belah yang berinteraksi dengan faktor tempat tumbuh. Selanjutnya, arah radial secara tunggal berpengaruh pada tegangan pada batas proporsi di KLS serta berinteraksi dengan faktor lainnya pada keteguhan belah. Kecenderungan arah aksial yang diperoleh ini berbeda dengan sampel jati muda (Wahyudi dan Arifien, 2005) maupun di jati dewasa dari tegakan Perhutani (Sulistyo dan Marsoem, 2000).

Dalam arah radial, efek juvenil kurang terlihat dalam eksperimen ini. Kayu juvenil atau muda yang dibentuk di awal pertumbuhan pohon memang kurang disukai karena kekuatannya yang lebih rendah (Shmulsky dan Jones, 2011). Efek tersebut hanya terlihat pada parameter batas proporsi KLS dimana nilai KD juga rendah di daerah dekat hati (Marsoem et al., 2014). Penelitian kayu jati India umur 35 tahun tumbuh di kebun menunjukkan penurunan nilai MoE, MoR, maupun MoR dari dekat kulit ke dekat hati (Thulasidas dan Bhat, 2012). Diduga efek juvenil ini kurang terlihat karena umur individu di Gunungkidul yang relatif muda sehingga proporsi kayu dewasanya masih rendah. Meski demikian, Miranda et al. (2011) yang meneliti jati dewasa di Timor Timur mendapatkan sifat mekanika tidak banyak berbeda dalam arah radial. Pola yang berbeda juga diperoleh Sulistyo dan Marsoem (2000) pada jati dewasa dari Perhutani. Disebutkan bahwa dalam arah radial, bagian tengah menunjukkan nilai tertinggi dalam parameter KLS.

\section{Hubungan Kerapatan Dasar dan Sifat Mekanika Kayu}

Sifat mekanika merupakan kombinasi dari sifat dasar seperti fisik, anatomi, dan kimia dari bahan baku kayu. Dalam beberapa hal, beberapa sifat dasar diukur dan digunakan untuk memprediksi kekuatan kayunya. Kerapatan rendah menandakan lebih banyaknya volume rongga dan dinding sel lebih tipis

Tabel 4. Koefisien korelasi kerapatan dasar dan sifat mekanika kayu jati.

\begin{tabular}{lcccrcccc}
\hline Keteguhan & KD & LS - BP & $\begin{array}{c}\text { LS - } \\
\text { MoR }\end{array}$ & $\begin{array}{c}\text { LS - } \\
\text { MoE }\end{array}$ & TTLS & TSS & Kekerasan & Geser \\
\hline LS - BP & $0,49^{* *}$ & & & & & & & \\
LS - MoR & $0,36^{* *}$ & $0,66^{* *}$ & & & & & & \\
LS - MoE & 0,09 & $0,23^{*}$ & $0,50^{* *}$ & & & & & \\
TTLS & $0,28^{* *}$ & 0,14 & 0,20 & $-0,15$ & & & & \\
TSS & 0,21 & 0,01 & 0,22 & 0,12 & $-0,37^{* *}$ & & & \\
Kekerasan & $-0,14$ & $-0,18$ & $-0,02$ & $-0,02$ & $0,32^{* *}$ & 0,20 & & \\
Geser & $0,40 * *$ & 0,20 & $0,30^{* *}$ & 0,01 & $0,50^{* *}$ & $0,31^{* *}$ & 0,14 & \\
Belah & 0,01 & $-0,07$ & 0,05 & 0,01 & 0,12 & 0,19 & 0,15 & 0,05 \\
\hline
\end{tabular}

Keterangan : Jumlah pengukuran sebanyak 81 sampel. LS-BP : lengkung statik - batas proporsi;

LS-MoR: lengkung statik - modulus patah; LS-MoR: lengkung statik - modulus elastisitas;

TTLS : tekan tegak lurus serat maksimum; TSS : tekan sejajar serat maksimum

** beda sangat nyata pada taraf uji $1 \% \quad *$ beda nyata pada taraf uji $5 \%$ 
dibandingkan kayu dengan kerapatan tinggi (Shmulsky dan Jones, 2011; Tsoumis, 1991). Untuk mengetahui besar hubungan antar parameter sifat mekanika dan KD maka dilakukan analisis korelasi Pearson (Tabel 4). Derajat korelasi tertinggi yang nyata antara kerapatan dasar dengan sifat mekanika diamati pada batas proporsi KLS $(r=0,49)$. KD berkorelasi positif secara signifikan terhadap MoR, TTLS, dan geser dengan derajat korelasi lemah sampai moderat. Oleh karena itu, dapat dikatakan bahwa semakin tinggi kerapatan dasar maka KLS, MoE, MoR, dan TTLS dimungkinkan juga semakin tinggi. Di lain pihak, KD tidak berkorelasi nyata terhadap MoR. Selanjutnya, korelasi MoE dan MoR menunjukkan nilai yang moderat $(\mathrm{r}=0,50)$ serta antara batas proporsi dan MOR $(\mathrm{r}=0,66)$.

Pada penelitian sebelumnya, Thulasidas dan Bhat (2012) mendapatkan korelasi sangat nyata antara KD dengan MoE $(r=0,49)$, MoR $(r=0,69)$, dan KTSS $(\mathrm{r}=0,70)$ di jati India serta korelasi nyata $(\mathrm{r}=$ 0,44-0,71) antar MoE, MoR, dan KTSS. Tidak ada korelasi yang berbeda nyata antara KD dan KTSS ini juga berbeda dengan hasil penelitian sebelumnya oleh Hadjib et al. (2005) maupun Hidayati et al. (2014) pada jati muda hasil pemuliaan di Indonesia. Derajat korelasi yang rendah dan tidak nyata antara KD dan beberapa sifat mekanika (LS-MOE, TSS, kekerasan, dan keteguhan belah) ini diartikan bila dalam pohon jati yang masih muda dan dipanen di hutan rakyat dengan kerapatan kayu yang relatif rendah belum tentu menghasilkan kekuatan yang inferior.

Derajat korelasi tertinggi antar parameter sifat mekanika yang diamati antara KTTLS dan keteguhan geser $(\mathrm{r}=0,50)$ ini berbeda dengan hasil yang diamati peneliti terdahulu (Perpinal dan Pietrarelli, 1995) dimana keteguhan geser tidak berkorelasi dengan sifat mekanika lainnya seperti di kayu
Prosopis sp. Selain itu, korelasi kuat antara MoE dan MoR di beberapa spesies telah diukur sebelumnya (Johanson 2002; Steffen et al., 1997; Firmanti et al., 2005). Bhat dan Priya (2004) telah mendemonstrasikan derajat korelasi kuat antara MoE dan MoR di jati baik pada umur 21 tahun maupun 65 tahun, serta korelasi kuat antara KTSS dengan MoE atau MoR di umur 21 tahun tetapi derajatnya lemah di umur 65 tahun. Nilai korelasi MoE dan MoR di penelitian ini adalah moderat $(r=0,50)$ serta tidak ada korelasi nyata MoE atau MoR dengan KTTSS. Hal ini cukup mengherankan karena pola korelasi sampel jati di Gunungkidul ini lebih mengikuti pola jati umur 65 tahun tersebut.

Berat jenis merupakan parameter terbaik dalam memprediksi sifat kekuatan kayu (Panshin dan de Zeeuw, 1980). Beberapa penelitian yang menghubungkan berat jenis dan sifat mekanika kayu di spesies lainnya memperoleh hasil yang bervariasi (Stalnaker dan Harris, 1989; Okai et al., 2004; Koch, 1964). Beberapa faktor yang menyebabkan lemahnya korelasi antara berat jenis dan kekuatan kayu antara lain keberadaan silika atau endapan mineral lainnya dalam sel, kadar resin, struktur jari-jari atau panjang serat (Okai et al., 2004), kadar lignin atau sudut mikrofibril dalam dinding sel (Koch et al., 2000; Bhat et al., 2001). Bhat dan Priya (2004) mengamati hubungan yang nyata antara beberapa sifat anatomi dan mekanika kayu di jati India serta kerapatan kayu tidak selalu bisa dihubungkan dengan sifat mekanisnya. Dari pengamatan 16 spesies, Zhang (1997) mendapatkan hasil kerapatan kayu lebih berkorelasi linear dengan MoR tetapi kurang linear dengan MoE. Selanjutnya disebutkan korelasi kurvi-linear lebih sesuai untuk parameter MoE. Untuk itu, selain eksplorasi sifat dasar kayu lainnya seperti sifat anatomi dan kimia, maka pendekatan dengan sampel yang lebih banyak serta pemodelan 
kurvi-linear perlu dicoba untuk menjawab derajat korelasi yang lemah di sampel jati Gunungkidul ini.

\section{KESIMPULAN}

Sifat mekanika kayu jati yang tumbuh di 3 tempat tumbuh di Gunungkidul termasuk dalam kelas kuat II-III. Tidak ada interaksi nyata antara tempat tumbuh, arah aksial, dan radial yang berpengaruh terhadap sifat mekanika yang diamati. MoE dan MoR dari KLS tidak dipengaruhi oleh ketiga faktor tersebut. Faktor tunggal tempat tumbuh berpengaruh nyata terhadap batas proporsi di KLS, keteguhan tekan tegak lurus serat, kekerasan, dan geser. Efek juvenil tidak terlihat di posisi radial hampir di semua parameter kekuatan kayu. Pengaruh nyata faktor aksial serta interaksi arah aksial dan radial hanya diamati pada keteguhan belah. Korelasi nyata antara KD dan sifat mekanika diamati di parameter batas proporsi, MoR, dan KTTLS dengan derajat lemah sampai moderat/sedang dan tidak ada korelasi nyata antara KD dan KTSS. Korelasi nyata yang moderat didapatkan antara MoE dan MoR dalam KLS serta antara KTTLS dan keteguhan geser.

\section{UCAPAN TERIMAKASIH}

Penelitian ini dibiayai melalui skema Hibah Kompetitif Penelitian Sesuai Prioritas Nasional Nomor: 177/SP2H/PP/DP2M/V/2009 - DIKTI. Penulis mengucapkan terima kasih kepada Henri Wasisto dan Aulia Dwi Laksono yang telah membantu teknis pengukuran di laboratorium.

\section{DAFTAR PUSTAKA}

Bhat KM \& Priya PB. 2004. Influence of provenance variation on wood properties of teak from the Western Ghat region in India. IAWA Journal 25, 273-282.
Bhat KM, Priya PB, \& Rugmini P. 2001. Characterisation of juvenile wood in teak. Wood Science and Technology 34, 517-532.

British Standard Institution. 1957. British Standard 373:1957. Testing small clear specimens of timber, BSI, London.

Dresch HE, \& Dinwoodie JM. 1996. Timber; Structure, Properties, Conversion and Use. Macmillan Press, London.

Firmanti A, Bachtiar ET, Surjokusumo S, Komatsu K, \& Kawai S. 2005. Mechanical stress grading of tropical timbers without regard to species. Journal of Wood Science 51, 339-347.

Hadjib N, Muslich M, \& Sumarni G. 2006. Sifat fisis dan mekanis kayu jati super dan jati lokal dari beberapa daerah penanaman. Jurnal Penelitian Hasil Hutan 24(4), 13-31.

Hidayati F, Ishiguri F, Iizuka K, Makino K, Marsoem SN, \& Yokota S. 2014. Among-clone variations of anatomical characteristics and wood properties in Tectona grandis planted in Indonesia. Wood and Fiber Science 46(3), 1-9.

Johanson CJ. 2002. Grading of timber with respect to mechanical properties. Timber engineering. Wiley, New York, 23-43.

Kementrian Kehutanan. 2012. Statistik Kehutanan Indonesia 2011. Kementerian Kehutanan. 205.

Koch J, Bauch J, Puls J, \& Schwab E. 2000. Biological, chemical and mechanical characteristics of "wulst-holz" as a response to mechanical stress in living trees of Picea abies [L.]. Holzforschung 54, 137-143.

Koch P. 1964. Wood Machining Processes. The Ronald Press Company. 74-76.

Marsoem SN. 2013. Studi mutu kayu jati di hutan rakyat Gunung Kidul. I. Pengukuran laju pertumbuhan. Jurnal Ilmu Kehutanan 7, 108-122

Marsoem SN, Prasetyo VE, Sulistyo J, Sudaryono, \& Lukmandaru G. 2014. Studi mutu kayu jati di hutan rakyat Gunung Kidul. III. Sifat fisika kayu. Jurnal Ilmu Kehutanan 8, 75-88.

Martawijaya A , Kartasudjana I, Kadir K, \& Amongprawira S. 2005. Atlas Kayu Indonesia Jilid I. Balai Penelitian Hasil Hutan. Badan Litbang Kehutanan. Bogor, Indonesia.

Miranda I, Sousa V, \& Pereira H. 2011. Wood properties of teak (Tectona grandis) from a mature unmanaged stand in East Timor. Journal of Wood Science 57, 171-178.

Okai R, Frimpong-Mensah K, \& Yeboah D. 2004. Characterization of strength properties of 
branchwood and stemwood of some tropical hardwood species. Wood Science and Technology 38(2), 163-171.

Panshin AJ \& de Zeeuw C. 1980. Textbook of Wood Technology. 4th Ed. Structure, Identification, Properties, and Uses of the Commercial Woods of the United States and Canada. McGraw-Hill Book Company, New York.

Perpinal E \& Pietrarelli L. 1995. Physical and mechanical properties of Prosopis flexuosa and Prosopis nigra wood from the Dry Chaco, Argentina. Holz als Roh- und Werkstoff 53, 83-85

Shmulsky R \& Jones PD. 2011. Forest Products and Wood Science: An Introduction, Sixth Edition. John Wiley \& Sons, Inc.

Stalnaker JJ \& Harris EC. 1989. Structural Design in Wood Structural Engineering Series. Van Nostrand Reinhold, 115 5th Avenue, New York, NY 10003. 120-127.

Steffen A, Johansson CJ, \& Wormuth EW. 1997. Study in the relationship between flat-wise and edge-wise moduli of elasticity of sawn timber as a means to improve mechanical strength grading technology. Hoz als Roh- und Werkstoff 55, 245-253.

Sulistyo J \& Marsoem SN. 2000. Pengaruh umur terhadap sifat fisika dan mekanika kayu jati (Tectona grandis L.f). Prosiding Seminar Nasional II MAPEKI. Yogyakarta, 2-3 September 1999. 49-63.

Thulasidas PK \& Bhat KM. 2012. Mechanical properties and wood structure characteristics of 35-year old home-garden teak from wet and dry localities of Kerala, India in comparison with plantation teak. Journal of Indian Academy of Wood Science 9(1), 23-32.

Tsoumis G.1991. Science and Technology of Wood. Van Nostrand Reinhold, New York.

Wahyudi I \& Arifien AF. 2005. Perbandingan struktur anatomis, sifat fisis, dan sifat mekanis kayu jati unggul dan kayu jati konvensional. Jurnal Ilmu \& Teknologi Kayu Tropis 3 (2), 9-15.

Yunianti AD, Wahyudi I, Siregar IZ, \& Pari G. 2011. Jurnal Ilmu \& Teknologi Kayu Tropis 9(1), 93-100.

Zhang SY. 1997. Wood specific gravity-mechanical relationship at species level. Wood Science and Technology 31,181-191. 